\title{
TOWARDS A NEGOTIABLE DEFINITION OF PROPAGANDA FOR INTERNATIONAL AGREEMENTS RELATED TO DIRECT BROADCAST SATELLITES
}

\author{
JON T. POWELL*
}

[S]atellite broadcasting should serve the purposes of peace, friendly relations, and understanding among peoples, of social and economic development particularly in the developing countries, of expanding the exchange of information and promoting cultural exchanges and enhancing the educational level of peoples of various countries. ${ }^{1}$

\section{INTRODUCTION}

The direct broadcast satellite (DBS) makes it possible to broadcast from space directly to the individual receiver. This technological opportunity to cross national boundaries and reach citizens of other nations has raised serious and divisive issues about the proper role of governments in the regulation of broadcasting as well as the individual's rights to freedom of speech and the free flow of information regardless of political frontiers. These issues, revolving around the concern about the potentially harmful effects of misused information-propaganda-form the basis for this inquiry into the debate over satellite broadcasting on an international scale. This controversy will be examined mainly in the context of United Nations discussions concerning satellite broadcasting and propaganda, and will offer some suggestions for resolving what at present appear to be irreconcilable differences.

Among the accusatory statements made during periods of international tension, few terms are more derogatory than "propaganda." When used as an invective, international propaganda has become identified with acts intended to change, destabilize, or subvert other countries' political, social, and economic systems by use of the mass media. The information that comes to be categorized as propaganda depends upon the political and social philosophies or ideologies involved.

The evolution of electronic communications, culminating in the development

\footnotetext{
Copyright (c) 1982 by Law and Contemporary Problems

* Professor of Communication Studies and Instructional Technology, Chairman of the Department of Communication Studies, Northern Illinois University.

1. 28 U.N. GAOR Committee on the Peaceful Uses of Outer Space at 10, U.N. Doc. A/AC.105/117 (1973). For DBS listing and performance characteristics see Satellite Performance Reference Wall Chart, SATELLITE COM., Mar. 1981, at 19-25 [hereinafter cited as Satellite Chart].
} 
of the DBS, has caused an impasse in international negotiations because of the concern over undesirable broadcasts. Instead of being welcomed as a means of improving global relations,' the development of the DBS on an international scale has engendered endless debate. The Assistant Deputy Minister, Space Programme, of the Canadian Department of Communications recently summarized the situation:

It is 24 years since the first artificial satellite achieved orbit. In that time dozens of spacecraft have successfully completed very complex missions in Earth orbit, as lunar probes and in planetary exploration. Progress over those 24 years has been outstanding.

It is 18 years since the first serious proposal was advanced for the use of satellites to broadcast television programmes directly to home receivers. In fact 14 years ago I heard a prediction, made in all seriousness, that within three years satellite broadcast service would be available throughout a specific country. . . . After 18 years of research we must ask if the broadcasting dream is an elusive myth or an imminent reality. ${ }^{2}$

Previous international negotiations, confronted by issues that challenge traditional concepts of information management, have not resulted in any significant agreements. In the case of the DBS, technology has become "a process of increasing the disproportion between cause and effect, has incalculably multiplied the potential consequences of human decisions, but has not significantly extended the motives by which men and governments are actuated." 3 While the DBS has provided greater opportunity for direct, instant communication, the net result thus far has been an ongoing confrontation between ideologies and principles rather than any concern for implementing an international system of satellite broadcasting.

Determining the international use of the DBS may be best approached by considering the DBS as a unique medium rather than a mere adjunct to some prior system of communication. ${ }^{4}$ Since the DBS represents a new instrument of communication, a new approach is needed to assist in the development of any definition of acceptable programming while avoiding, insofar as possible, direct confrontation with those conflicting information policies which have thus far resulted in a stalemate.

As the term "negotiable definition" contained in the title indicates, it is the purpose of this treatise to explore the concern over propaganda as it relates to the DBS, and to suggest some interpretations and mechanisms which might assist the development of international space broadcasting. "Negotiable" in this case simply means determining what could be negotiated, and indicating some means of implementing any agreement. The term "propaganda," as will be seen, cannot be given a universal definition, but only a situational context, if the current predicament is to be resolved.

To achieve these purposes, this article includes sections describing the interna-

2. Curran, DBS: Myth or Reality, 9 INTERMEDIA 27 (1981).

3. G. Hugo, Appearance and Reality in INTERnational Relations 11 (1970).

4. 24 U.N. GAOR Committee on the Peaceful Uses of Outer Space at 4, U.N. Doc. A/AC.105/49 (1969). See Broadcasting from Satellites, a working paper submitted by Canada and Sweden to the UN Working Group on Direct Broadcast Satellites (WGDBS). As noted therein, "It may be significant that at the 1968 U.N. Space Conference in Vienna the view was expressed that satellites should be considered as completely new tools, the structure of which is not an extension of previous inventions." 
tional nature of DBS negotiations, the issues that surround those negotiations, the suggested development of a negotiated definition for propaganda, and some recommendations for the implementation of any negotiated definition. Since many United Nations documents officially proclaim a number of conflicting rights (e.g., freedom of information, national sovereignty, and noninterference in internal affairs), with a resulting deadlock in DBS negotiations, this study makes frequent use of verbatim records as well as official documents in order to examine the interplay of competing ideas. The principal materials used are the verbatim records of the UN Committee on the Peaceful Uses of Outer Space (COPUOS), the Working Group on Direct Broadcast Satellites (WGDBS), United Nations documents, and U.S. Government documents.

II

\section{The InTERnational Context of DBS Negotiations}

As long as DBS service remains within national borders, the problems of program regulation are essentially internal. Once broadcasting from space reaches across national boundaries, however, the issues become global and require international cooperation. No single nation can unilaterally provide satisfactory solutions to problems raised by international broadcasts.

\footnotetext{
Broadcasts from one satellite may, in the future, be able to cover one third of the earth's surface, and with suitable technical arrangements it would, in principle, be possible to reach the greater part of the Earth from one point of origin. One salient feature of direct broadcast systems is the theoretical possibility of being able to reach about $90 \%$ of the world's population with the help of only three satellites and one earth station originating the programme. International broadcasting from satellites therefore goes beyond the sphere and scope of any national institution. 5
}

In a global context, the DBS raises two distinct but interrelated issues-the control of space and the regulation of satellite broadcasting. Since the satellite must be placed in a fixed orbit in a corridor of space above the earth, questions of national security, sovereignty, ownership, and reservation of orbital positions become important topics for negotiation.

If only matters of the transit or positioning of a space object were involved, international agreement could be greatly simplified. But the DBS presents a unique situation in regulation because national policies related to broadcasting differ widely according to political ideology, constitutional principles, and national development. Although the potential good of a DBS system is recognized, the spectre of social turmoil aroused by uncontrolled television signals reaching from space into the individual mind without any possibility of regulation, threatens many governments.

The following paragraphs, selected from the preamble of the 1966 United Nations Treaty on Principles Governing the Activities of States in the Exploration and Use of Outer Space, including the Moon and Other Celestial Bodies, illustrate how space and communication policies reflect the concern over propaganda.

5. 24 U.N. GAOR Committee on the Peaceful Uses of Outer Space at 68-69, U.N. Doc. A/AC.105/49 (1969). 
Recognizing the common interest of all mankind in the progress of the exploration and use of outer space for peaceful purposes,

Desiring to contribute to broad international co-operation in the scientific as well as the legal aspects of exploration and use of outer space for peaceful purposes,

Believing that such co-operation will contribute to the development of mutual understanding and to the strengthening of friendly relations between States and peoples,

Taking account of United Nations General Assembly resolution 110 (II) of 3 November 1947, which condemned propaganda designed or likely to provoke or encourage any threat to the peace, breach of the peace or act of aggression, and considering that the aforementioned resolution is applicable to outer space. ${ }^{6}$

Whatever can be negotiated in the area of progaganda must also be implemented, taking into account the policies and traditions of international law. "It is apparent to all of us that a successful conclusion to the direct-broadcast-satellite (DBS) negotiations requires a thorough understanding and careful balancing of complex legal, technical and political factors," and cooperation "should be based on appropriate principles and norms of international law."8 Arthur Goldberg once stated that "Man's survival in outer space would . . . depend not only on his amazing technology but also on the rule of law among nations."9

The 1979 World Administrative Radio Conference (WARC 1979) underscored the need for an international rule of law because, as one author put it, "If the interests of all countries are to be met, the basic legal issues must be squarely addressed and an equitable, administratively convenient, yet flexible solution devised."'o Such a formula would recognize that the basic arguments, however defined, end up as legal issues and as such must be "resolved on a clear-cut legal basis," " governed by "international principles . . . of a binding character."12

At the same time, national tradition in broadcast regulation forms the basis for international cooperation, and that tradition remains just as strong as any government's concern for the effects of broadcasting.

Whatever may be the legal form adopted in the various countries for the establishment and operation of broadcasting services, these services are subject, in all countries, to special regulations due to the characteristics of the medium itself. It can therefore be said that governments, in view of the technical difficulties resulting from the limited number of frequencies available, the importance of broadcasting in the formation of public opinion and the incidence of their operations on law and order, have found themselves obliged to regulate broadcasting activities. ${ }^{13}$

The evolution of direct broadcast satellites represents both a challenge and an

6. 21 U.N. GAOR (1499th plen. mtg.) (Agenda Item 30) Annex at 3, U.N. Doc. A/Res/2222 (1966). The complete text of all United Nations General Assembly Resolutions may be found in UNITED NATIONS RESOlutions (D. Djonovich ed. 1966).

7. 35 U.N. GAOR Committee on the Peaceful Uses of Outer Space (213th mtg.) at 23-25, U.N. Doc. A/AC. 105/PV. 213 (1980).

8. 28 U.N. GAOR Committee on the Peaceful Uses of Outer Space at 11, U.N. Doc. A/AC.105/117 (1973).

9. G.A. Res. 2222, 21 U.N. GAOR Supp. (No. 16) at 13, U.N. Doc. A/6316 (1966).

10. Rutkowski, Six Ad-Hoc Two: The Third World Speaks Its Mind, 4 SaTellite Com. 27 (1980).

11. 35 U.N. GAOR Committee on the Peaceful Uses of Outer Space (212th mtg.) at 13-15, U.N. Doc. A/AC.105/PV.212 (1980).

12. 29 U.N. GAOR Committee on the Peaceful Uses of Outer Space at 14, U.N. Doc. A/AC. $105 / 117$ (1973).

13. 24 U.N. GAOR Committee on the Peaceful Uses of Outer Space at 5-6, U.N. Doc. A/AC.105/49 (1969). 
opportunity. As a working paper submitted by Canada and Sweden over a decade ago concluded:

The development of broadcasting via satellite presents mankind with unprecedented possibilities to assist in solving some of the more urgent needs of the developing countries, to achieve efficient and increased flow of information and to reduce the isolation of countries, communities and individuals; men and women everywhere will become more conscious of their worldwide environment. Such opportunities carry with them commensurate responsibilities. The common interest in taking full advantage of these opportunities demands common action. As all other space activities, satellite broadcasting is inherently international, or rather planetary, in character. It therefore requires action at the same level. The penalty for failing to act will be severe; not only will a lack of action compromise the interests of countries, individually or collectively, it may also lead to a chaotic situation, thereby impairing relations between countries. ${ }^{14}$

The DBS cannot be used satisfactorily on an international scale, because "globally accepted legal rules concerning programme content do not exist at present,"15 and space broadcasting goes both "beyond the sphere and scope of national mass media institutions," 16 and beyond the historical approach to the control of media. The "direct broadcast satellite, can, if we like, be one of the instruments of the broadcasting of interdependence," because the DBS "needs interdependence to operate," 17 an interdependence that at present has no counterpart in international law.

No single nation can solve the problems posed by the DBS because of the satellite's unique international nature and because of the diverse national policies which reaffirm the need for a rule of law. As one COPUOS delegate noted, international organization is essential to the development of international broadcasting. ${ }^{18}$ The possibility of broadcasting from space has brought nations face to face for purposes of negotiation, yet these nations remain far from agreement.

III

\section{International Issues Affecting a Negotiable Definition}

The international debates surrounding DBS control have recognized that, "[t]he foreseeable effects and implications of satellite systems must be seen against the background of the general political, social, economic and technological environments into which they are introduced," 19 but the confusion of those competing environments burdens the efforts to negotiate. Although closely interrelated and difficult to isolate, the issues of individual rights, the free flow of information, national sovereignty, prior consent, noninterference, avoidance of conflict, protection for developing nations, and finally, the concept of common heritage will be examined briefly in this section because they create the background of competing

14. Id. at $78-79$.

15. Id. at 76 .

16. Id. at 71 .

17. D'Arcy, Broadcasting in the Global Age, 43 Combroad 2 (1979).

18. 34 U.N. GAOR Committee on the Peaceful Uses of Outer Space (192d mtg.) at 12, U.N. Doc. A/AC.105/PV.192 (1979).

19. 24 U.N. GAOR Committee on the Peaceful Uses of Outer Space at 3, U.N. Doc. A/AC.105/49 (1969). 
concepts which affect both DBS negotiations and negotiations over propaganda control.

\section{A. Individual Rights}

The development of communication satellites has been described as fostering three trends: "abundance," "planetarisation," and "individualisation."2o "Abundance" refers to the large channel capacity of satellites which, along with other communications technologies, changes a scarce resource into a plentiful one while current thinking remains "fixed in the psychology of scarcity and exceptionality." 21 The term "planetarisation" means that no part of earth may be out of range for a communications satellite, and it may well be, as Arthur Clarke predicted, that by the year 2000 satellites will have determined "mankind's second language throughout the world."22 "Individualisation" recognizes that the era of mass communication is evolving into an era of mass individual communication. Miniaturization and microprocessing methods such as teletex, tele-data-processing, and interactive networking, are restoring the individual's role and right to be free of authority and monopoly in communications. ${ }^{23}$

It is within the framework of this mass international individualization of commmunication made possible by the DBS, that the basic human right to information, espoused in numerous UN documents and national constitutions, ${ }^{24}$ is debated. Unabridged, this right conflicts with the basic principles embodied in the concepts of national sovereignty and prior consent discussed below. The international issues of individual freedom of expression and access to information raise a panoply of competing interests. For example, one argument emphasizes that individual human rights are absolute, while another argument asserts that national survival requires limiting such rights. Inevitable dilemmas arise, with each side relying upon analysis and evidence of apparently equal merit.

The United Kingdom has pointed to UN affirmations to weigh the validity of human rights against those of the state.

First, in connexion with direct broadcasting from satellites, the United Kingdom is well aware, and has great sympathy with, the contention that States have the right to choose their own social systems and their own cultures, as well. However, we believe that this Committee should not lose sight of the fact that States and peoples are composed of individuals, and that individuals also have a right of choice in the fields of information, social questions and of culture.

In connexion with the principle relating to consent and participation, therefore, my delegation does not consider that States enjoy absolute sovereign rights in respect of the information available in their territories. Such sovereign rights might have been enjoyed in the past, but at present a large number of international instruments proclaim freedom of information, regardless of frontiers. These instruments include the Universal Declaration of Human Rights, article 19; the International Covenant on Civil and Political Rights, article 19; the European Convention on Human Rights, article 10; the American Declaration on

20. D'Arcy, supra note 17, at 3.

21. Id. at 3 .

22. Id. at 3-4.

23. Id. at 4 .

24. See Powell, Direct Broadcast Satellites: The Conceptual Convergence of the Free Flow of Information and National Sovereignty, 6 CAL. W. INT'L L.J. 1 (1975). 
the Rights and Duties of Man, article 4; and the Declaration on Principles embodied in the Final Act of the Helsinki Conference on Security and Co-operation in Europe. ${ }^{25}$

On the other hand, when the issue becomes a matter of national survival or political sovereignty, the right of the state may be held preeminent in the arena of competing rights.

Under the concept of not limiting nationally the individual freedom of choice, we have seen our attempts to arrive at an agreement on the principles governing direct satellite television broadcasting frustrated. The argument of the right to information has been advanced in connexion with the crucial question of prior consultation and agreement, to which developing countries attach so much importance, perhaps because they know quite well that when the mass media belong to a single source, the freedom of choice is illusory, whereas there is a very real danger of losing their cultural identity, of receiving tendentious information, distorted by alien interests, and even the danger of interference in their internal affairs. The absolute right to inform or to express oneself does not exist. In any country this right is subject to rules and regulations, and these rules and regulations not only vary from country to country but sometimes also vary from province to province within the same State, because what is acceptable in a given community might not be acceptable in the neighbouring community, depending on variations in moral and cultural patterns. So what are the rules that are going to regulate the contents of broadcasts which will cover entire continents from space? For the sake of freedom of information, should we accept as universally valid one single standpoint, one single moral standard? This is a question. ${ }^{26}$

In contrast to this explanation and justification for a flexible approach to the principle of individual freedom, the U.S. perspective, which has constitutional sources, reflects a commitment to the absence of government intervention- "Congress shall make no law . . . ."27 The first amendment has been called "the centerpiece of United States information policy" which "stands for the principle of open information exchange," and "for the creation of a 'marketplace of ideas." "'28

\section{B. Free Flow of Information}

The international free flow of information, as a general principle, can be found in the United Nations Universal Declaration of Human Rights, article 19, which states, "Everyone has the right to freedom of opinion and expression; this right includes freedom to hold opinions without interference and to seek, receive and impart information and ideas through any media and regardless of frontiers."29

25. 31 U.N. GAOR Committee on the Peaceful Uses of Outer Space (163d mtg.) at 18-20, U.N. Doc. A/AC.105/PV.163 (1976).

26. 32 U.N. GAOR Committee on the Peaceful Uses of Outer Space (173d $\mathrm{mtg}$.) at 42, U.N. Doc. A/AC. 105/PV.173 (1977).

27. U.S. CONST. amend. I.

28. A. Bushkin \& J. Yurow, The Foundations of United States Information Policy 6 (1980)

29. G.A. Res. 217A, art. 19, U.N. Doc A/810, at 71 (1948), reprinted in BASIC DOCUMENTS IN INTERNATIONAL LAW 135 (I. Brownlie ed. 1967) (emphasis added).

The Declaration is not a legally binding instrument as such, and some of its provisions depart from existing and generally accepted rules. Nevertheless some of its provisions either constitute general principles of law (see the Statute of the International Court of Justice . . . art. 38 (I) (c)), or represent elementary considerations of humanity. More important is its status as an authoritative guide, produced by the General Assembly, to the interpretation of the Charter. In this capacity the Declaration has considerable indirect legal effect, and it is regarded by the Assembly and by some jurists as a part of the "law of the United Nations." On the Declaration, see Oppenheim, International Law', 8th ed., i. Pp. 744-6; Waldock, 106 Recueil des Cours de l'Academie de Droit International (1962,II), Pp.198-9; 
The result of U.S. promulgation of first amendment principles in international negotiations has been twofold. First, there has been clear resistance to the U.S. position, and second, DBS negotiations have stalemated. Strict adherence to constitutional principles has placed the United States in a somewhat isolated position regarding the free flow of information.

Long overdue is a reweighing of past applications of the "free flow of information" doctrine. The doctrine itself arises from constitutional principles that no sensible person seriously questions. But these principles have to be applied realistically in terms of the actual channels through which information flows. Other governments, while continuing to respect our constitutional principles, have shown with startling unanimity and unmistakable clarity that they want to take a fresh look at modern application of these principles. Our isolation has grown in the 2 years since U.N. debates on direct broadcasting via satellites found the U.S. deserted even by its staunchest allies. ${ }^{30}$

A French COPUOS delegate was careful to distinguish the pure concept of a completely unrestricted free information flow and its practical application in a global context involving different national systems. He suggested that for developed nations, the opportunities available for selecting information reduced its risk. An extrapolated version of the French interpretation follows:

In view of France's traditional philosophy, . . . we are in favour of the greatest possible freedom for television broadcasting by satellite because, like others, we believe that freedom of information is the very basis of freedom itself . . . .

On the one hand, it makes no distinction between information, in the strictest sense of the word, and propaganda. . . . On the other hand, if, when addressed to industrialized societies already having a diversity of sufficient information, complete freedom of information permits users to have a real choice-such freedom making possible the expression of opposite viewpoints which can neutralize excesses-that does not apply to those societies not possessing diversified systems of information. ${ }^{31}$

The 1972 UNESCO Declaration of Guiding Principles on the Use of Satellite Broadcasting for the Free Flow of Information, the Spread of Education and Greater Cultural Exchange cautiously approached the international issues that might arise from widely divergent policies toward the free flow of information. This Declaration qualified the concept of absolute free flow by linking satellite broadcasting to a series of rights, while recognizing the preeminence of national decisionmaking. For example, the Declaration states that "Satellite broadcasting shall be apolitical and conducted with due regard for the rights of individual persons . . . as recognized by States and international law."32

Verdoodt, Naissance el Signification de la Dëclaration Universelle des Droits de l'Homme, 1964. Generally on human rights see Lauterpacht, Intemational Law and Human Rights, 1950; Ganji, Intemational Protection of Human Rights, 1962; Ezejiofor, Protection of Human Rights under the Law, 1964; Robinson, The Universal Declaration of Human Rights, 1958; McDougal and Bebr, 58 American Journal of Intermational Law (1964), pp. 603-41; and 11 Howard Law Joumal, Spring 1965.

Id. at 132 .

30. Crawford, Toward an Information Age Debate, CHRON. INT'L COM. 3 (1980)

31. 31 U.N. GAOR Committee on the Peaceful Uses of Outer Space (160th mtg.) at 12-15, U.N. Doc. A/AC.105/PV.160 (1976).

32. 17 UNESCO Annex Doc. $17 \mathrm{C} / 98$ art. II, para. 2 at 3 (1972), 4 U.N. Doc. A/AC.105/109 (1973) [hereinafter cited as Declaration of Guiding Principles]. Other relevant passages include the following:

Recognizing that the development of communication satellites capable of broadcasting programmes for community or individual reception establishes a new dimension in international communication. Recalling that under its Constitution the purpose of Unesco is to contribute to peace and security by promoting collaboration among the nations through education, science and culture, and that to 
Another example of the difficulty involved in negotiating a free flow of infor-

realize this purpose, the Organization will collaborate in the work of advancing the mutual knowledge and understanding of peoples through all means of mass communication and to that end recommend such international agreements as may be necessary to promote the free flow of ideas by word and image.

Recalling that the Charter of the United Nations specifies, among the purpose and principles of the United Nations, the development of friendly relations among nations based on respect for the principle of equal rights, the non-interference in matters within the domestic jurisdiction of any State, the achievement of international co-operation and the respect for human rights and fundamental freedoms.

Bearing in mind that the Universal Declaration of Human Rights proclaims that everyone has the right to seek, receive and impart information and ideas through any media and regardless of fronticrs, that everyone has the right to education and that everyone has the right freely to participate in the cultural life of the community, as well as the right to the protection of the moral and material interests resulting from any scientific, literary or artistic production of which he is the author.

\section{Article IV}

1. Satellite broadcasting provides a new means of disseminating knowledge and promoting better understanding among peoples.

2. The fulfillment of these potentialities requires that account be taken of the needs and rights of audiences, as well as the objectives of peace, friendship and co-operation between peoples, and of economic, social and cultural progress.

\section{Article V}

1. The objective of satellite broadcasting for the free flow of information is to ensure the widest possible dissemination, among the peoples of the world, of news of all countries, developed and developing alike.

2. Satellite broadcasting, making possible instantaneous worldwide dissemination of news, requires that every effort be made to ensure the factual accuracy of the information reaching the public. News broadcasts shall identify the body which assumes responsibility for the news programme as a whole, attributing where appropriate particular news items to their source.

\section{Article VI}

2. Each country has the right to decide on the content of the educational programmes broadcast by satellite to its people and, in cases where such programmes are produced in co-operation with other countries, to take part in their planning and production, on a free and equal footing.

$$
\text { Article VII }
$$

1. The objective of satellite broadcasting for the promotion of cultural exchange is to foster greater contact and mutual understanding between peoples by permitting audiences to enjoy, on an unprecedented scale, programmes on each other's social and cultural life including artistic performances and sporting and other events.

2. Cultural programmes, while promoting the enrichment of all cultures, should respect the distinctive character, the value and the dignity of each, and the right of all countries and people to preserve their cultures as part of the common heritage of mankind.

Article VIII

Broadcasters and their national, regional and international associations should be encouraged to co-operate in the production and exchange of programmes and in all other aspects of satellite broadcasting including the training of technical and programme personnel.

Article IX

1. In order to further the objectives set out in the preceding articles, it is necessary that States, taking into account the principle of freedom of information, reach or promote prior agreements concerning direct satellite broadcasting to the population of countries other than the country of origin of the transmission.

2. With respect to commercial advertising, its transmission shall be subject to specific agreement between the originating and receiving countries.

\section{Article X}

In the preparation of programmes for direct broadcasting to other countries, account shall be taken of differences in the national laws of the countries of reception.

\section{Article XI}

The principles of this Declaration shall be applied with due regard for human rights and fundamental freedoms. 
mation while avoiding what might be subject matter for propaganda is illustrated by UN Resolution 2448 (XXIII), passed December 19, 1968, which reads in part:

Recalling the deep interest which the United Nations has shown since 1947 in problems of freedom of information and the various measures thus far inadequate, which it has taken to promote and safeguard this freedom,

Mindfulthat recent technological advances in the field of telecommunications have, by enormously extending the reach and scope of words, images and ideas, greatly magnified the potentialities, for good or evil, of the media of information,

Believing that the time has come for the international community to take a a renewed interest in measures calculated to promote freedom of information and to encourage the responsible exercise of this freedom,

1. Affrms the principle that the primary function of media of information anywhere in the world is to gather and impart freely and responsibly objective and accurate information;

2. Emphasizesthat the objectives of freedom of information could best be attained if everyone had access to diverse sources of news and opinions;

3. Recommends to all States and international organizations concerned that freedom of information should be particularly promoted in the case of dissemination of information on the evils of apartheid, racism, nazism, colonialism and racial discrimination;

4. Appeals to the media of information everywhere to co-operate in the strengthening of democratic institutions, the promotion of economic and social progress and friendly relations among nations, and combating propaganda for war or for national, racial or religious hatred in accordance with the principles of the United Nations. ${ }^{33}$

Beneath statements of broad and ideal principle, there lurks a fear that in negotiating a free flow of information policy, the stronger participant, not necessarily the better concept, will rule. The negotiating effort itself may be seen as favoring those who can afford to be better prepared. The 1979 WARC in Geneva, for example, found the United States investing much more effort than others, as described by Anthony Smith:

One may cite as an example the case of the World Administrative Radio Conference of
1979 held in Geneva at which the complex technical arguments over the organization of use
of the electro-magnetic spectrum-radio wavelengths--was carried out. The American del-
egation had a staff in Geneva of more than a hundred, compared with one or two from
some of the smallest countries; nearly a thousand people had been involved in preparing the
US plans for this important general WARC; with the use of massive computer expertise the
US had mapped out a negotiating position covering the entire spectrum from 1 hertz to 387
gigahertz with a complex set of fallback positions. The delegation had also collected all
known facts concerning the positions of all other delegations as well as informal information
collected in private briefings and everything relevant that could be found out about the
members of all of the other delegations. The whole of this information could be held on-
line and could be retrieved in a matter of moments. It provided the United States with a
tremendous advantage over all of its rivals. The world power game has moved into an
information phase. ${ }^{34}$.

Smith had earlier pointed out that "national independence is more than ever dependent upon . . . handling of information" and that information rights can include "privacy and non-communication rights" as well as the basic right "to provide and receive" information. ${ }^{35}$ This right to provide and receive information, therefore, may also include the right not to communicate and to be protected from

33. G.A. Res. 2448, 23 U.N. GAOR Supp. (No. 18) at 52-53, U.N. Doc. A/7218 (1968).

34. A. Smith, The Geopolitics of Information: How Western Culture Dominates the WORLD 115 (1980).

35. Id. at 114 . 
public exposure where privacy (as a matter determined by social or cultural standards) might be violated.

At one end, the free flow principle was affirmed by a West German COPUOS delegate, who declared that the DBS must not be limited so as to deny human rights regardless of political frontiers, as established by such international instruments as the UN Universal Declaration of Human Rights, the Council of Europe, the Final Act of the Helsinki conference and the activities of UNESCO. ${ }^{36}$ At the other end, the Soviet Union demanded that the principle of the free flow of information recognize national sovereignty to assure that no interference with internal affairs takes place. ${ }^{37}$ The German Democratic Republic (GDR) reflected this same viewpoint.

Freedom of information is a human right. The exercise and protection of human rights falls, however, within the scope of domestic law. Only the State is entitled to provide its citizens on its territory with information in accordance with, and with respect for, the principles of international law. For instance, article 27 of the socialist Constitution of the German Democratic Republic, inter alia, stipulates that "every citizen . . . has the right, in accordance with this Constitution, to express his opinion freely and publicly.... . Freedom of press, radio and television is guaranteed."

It is recognized in international law that the flow of information has to be in harmony with the domestic laws of the State concerned and that "the protection of national security, public order, or of public health or morals" must be ensured. ${ }^{38}$

\section{National Sovereignty}

National sovereignty, as it relates to the flow of information across frontiers, was not as sensitive an issue when only printed material existed. Printed material can be physically controlled at a nation's border. Radio broadcasting across borders continues to be tolerated, though not without some complaint.

However, new threats to national sovereignty have surfaced because television broadcasting from space has far greater persuasive potential than radio or printed materials.

[It could] exert a powerful influence on social patterns throughout the world. The prospect of being able to tune into television broadcasts from a choice of a range of stations in far distant countries opens up new horizons for the viewer. Satellites in geo-stationary orbit could provide a twenty-four-hour service to a substantial part of the earth's population, and, in so doing, make a major contribution to international understanding or, if misused, arouse political tension on an unprecedented scale. ${ }^{39}$

Propaganda, uncontrolled and broadcast from space, could seriously threaten those national rights which are claimed to assure individual protection and political stability. The DBS has been described as "the very hinge between . . . human freedom and intrusion . . . of a technique for the dissemination of thought which

36. 33 U.N. GAOR Committee on the Peaceful Uses of Outer Space (182d mtg.) at 12-13, U.N. Doc. A/AC. 105/PV. 182 (1978).

37. 35 U.N. GAOR Committee on the Peaceful Uses of Outer Space (212th mtg.) at 36, U.N. Doc. A/AC. 105/PV.212 (1980).

38. 30 U.N. GAOR Committee on the Peaceful Uses of Outer Space (150th mtg.) at 3-5, U.N. Doc. A/AC.105/PV.150 (1975).

39. 24 U.N. GAOR Committee on the Peaceful Uses of Outer Space at 4, U.N. Doc A/AC.105/65 (1969). 
is so powerful it can . . exalt or trample on this very freedom." 40

The power of propaganda places upon any originating nation new responsibility. A 1963 UN resolution entitled Declaration of Legal Principles Governing the Activities of States in the Exploration and Use of Outer Space indicates that "States bear international responsibility for national activities in outer space . . . " "41 Since space satellites open up a variety of opportunities for activities that cross national boundaries-communication, earth-sensing, weather observation, for example-the more sophisticated the technology becomes, the greater the concern for its international implications.

In 1972, the UN General Assembly called for the development of principles to govern the use of direct broadcast satellites, recognizing "the need to ensure the free flow of communications on a basis of strict respect for the sovereign rights of States." ${ }^{2}$ Similar UN resolutions ${ }^{43}$ have emphasized international responsibility, national sovereignty, and the free flow of information while qualifying the affirmation of freedom of information with references to sovereign rights. Thus, squeezed between the issues of free flow and sovereignty, the prospect of uncontrolled propaganda remains as a foreboding presence, sometimes unstated but always implied. This implication suggests that the principle of absolute freedom to communicate any and all information across national boundaries becomes conditional, dependent upon the anticipated threat of unacceptable information (propaganda). Whatever the basis of judgment for unacceptable or acceptable information, the principle of free flow of information is generally recognized except where it appears to contradict the concept of national sovereignty.

\section{Prior Consent}

One way to recognize national sovereignty, and regulate satellite programming, is to invoke the principle of prior consent. Any prior consent arrangement would require agreement that the receiving nation approve a broadcast before it is made to its people. Such an agreement recognizes the right of a state to determine beforehand the propriety of a communication to its citizenry. Since the prior consent concept means that a receiving nation must first give permission before a satellite can broadcast a program, the United States is placed in an awkward situation. If it agrees to the principle of prior consent, the U.S. Constitution is violated. But if the United States does not agree to prior consent, negotiations will stall. As one U.S. delegate commented during COPUOS disscussions: "[W]e must be most careful in developing these international guidelines to ensure the protection of the principle and, to the greatest extent that it exists, of the practice of free and open exchange of information and ideas." 44

40. 30 U.N. GAOR Committee on the Peaceful Uses of Outer Space (153d mtg.) at 12, U.N. Doc. A/AC.105/PV.153 (1975).

41. G.A. Res. 1962, 18 U.N. GAOR Supp. (No. 15) at 15, U.N. Doc. A/5515 (1963).

42. G.A. Res. 2916, 27 U.N. GAOR Supp. (No. 30) at 14, U.N. Doc A/8730 (1963).

43. See infra note 66 .

44. 31 U.N. GAOR Committee on the Peaceful Uses of Outer Space (163d mtg.) at 47, U.N. Doc. A/AC.105/PV.163 (1976). The following passage appears even more restrictive:

I want to affirm our position that direct broadcast principles must not infringe upon the internation- 
In attempting to reconcile this conflict, the United States has been described as officially having "no single national policy, but rather a composite of policies, explicit and implicit, about information."45 Actually, U.S. policy can be divided into two broad categories-the legal foundations of information policy, and the economics and management of information. The legal category assumes a "policy of openness," while the economic and management category recognizes social and organizational efficiency, and economic policies affecting both the distribution of information and the free market place. ${ }^{46} \mathrm{~A}$ French delegate described the

ally recognized right to seek, receive and impart information and ideas through any media and regardless of frontiers. Although the United States has no plan to engage in direct broadcast by satellite internationally, we remain unable to accept a formula which is open to the interpretation that prior consent is required before establishing a direct broadcast system or initiating a particular broadcast.

33 U.N. GAOR Committee on the Peaceful Uses of Outer Space (180th mtg.) at 22, U.N. Doc. A/AC. 105/PV.180 (1978).

45. A. Bushkin \& J. YuRow, supra note 28 , at 4.

46. Id. at 4-5. This paper, subtitled "A United States Government Submission to the High-Level Conference on Information, Computer, and Communications Policy Organization for Economic Cooperation and Development, October 6-8, 1980, Paris, France," lays the foundation for the U.S. policy as follows:

As we enter the 1980's, one of the increasingly important issues on the international agenda is the How of information across national boundaries. Information policies are policies about the conditions of information availability. Intemational information policy issues arise not only as a result of the increasing awareness of the importance of information within a nation's internal affairs, but also as a logical consequence of the growing international exchange of information, in the form of both goods and services.

Our entrance into the new decade is marked by common awareness among many nations of the world that it is important to undertake -or, in many cases, simply to continue in greater depth-an examination of the role of information, as well as information technology, in their national affairs. This is both a valid endeavor in its own right and a prerequisite to participation in the growing international debate on these issues.

Just as a nation's overall foreign policy fundamentally tends to reflect its domestic policy perspectives, so too do a nation's international information policies reflect its domestic information policy perspectives. Moreover, if a nation examines its own domestic information policies in the process of formulating its international information policies, the result will be more coherent policies and a better representation of that nation's interests. However, it is difficult to delineate a country's domestic information policies with sufficient precision so as to be able to articulate with clarity what that nation's international information policy interests are. And, of course, a country cannot simply extend its domestic policies into the international arena, since it must also consider, and to a certain extent accommodate, the interests of other nations.

The development of both domestic and international information policies, although possibly a very elusive goal, is an important governmental endeavor because information has properties which underlie the effective functioning of modern society. Some of these properties are:

- Information is a resource. Like energy, capital, or labor, information is a resource that can be applied to achieve economic, social, or political goals.

- Information is a commodity. Information is sold, traded, or otherwise exchanged frequently for financial or other reward to the person or organization sharing or giving up the information.

- Information can conserve resources and enhance productivity. The effective acquisition and use of information can save other resources or turn them to more productive uses.

But perhaps even more interesting from a public point of view, information can also affect relationships in two very important ways:

- Information can mediate relationships. Information about an individual, for example, often forms the basis for his relationships with institutions or other individuals. The same is true of relationships between industries, firms within an industry, governmental units, or nations.

- Information can change relationships. Changes in the concentrations or flows of information can alter traditional relationships and power balances among people, organizations, governmental units, or nations.

Id. at $2-3$. 
dilemma:

The problem of direct television broadcasting is the most delicate matter, in our view, because . . . the problem to be solved here lies at the point of intersection between the universal requirements of human freedom and the intrusion of a technique for disseminating thought into daily life which, because of its power and depending on how it is used, may consecrate or cast doubt on this very freedom . . . . The French delegation continues to favour the search for an over-all compromise based on a fair balance between, on the one hand, the interests of the transmitting countries and the principles they invoke and, on the other hand, the protection of the rights of the receiving countries . . . .

I would remind you that the free circulation of information would prove to be an illusion if it gave rise to a unilateral right for the most developed countries to carry out, without some quid pro quo, direct television broadcasts to the countries which are least developed and thus more vulnerable to action from outside. It must also be possible to protect the freedom of those countries so that these broadcasts do not damage their cultural identity and their legitimate ideals. ${ }^{47}$

The Soviets, while recognizing that some nations object to such terms as "consent" and "prior consent," and others prefer "agreement" or "accord," stressed that the principle remains the same because "the State at which the broadcasting is directed should be informed that there is a broadcast that is going to be transmitted to it, and it should have the right to express its approach to this, either negative or positive. . . but the principle of the necessity for mutual agreement remains valid."48

In contrast to the Soviet Union, the United Kingdom affirmed that it is "one of those countries which does not believe that the principle of prior consent by receiving States should be applied."49 Although this statement at first appears absolute, a hint of compromise follows: "[W]e recognize that there should be a duty, wherever possible, for the broadcasting State to co-operate with the receiving State in a way that would lead to harmonious participation by the receiving State in any direct-broadcast-satellite programme."50 A French delegate refined this viewpoint by stating that since any arrangement "must guarantee a balance of rights," there "are certain rights we cannot ignore . . . the right of granting, and therefore the right of withdrawing, authority to broadcast."51

In contrast to the exercise of prior restraint by the receiving country, the control of "spillover" would originate with the nation using the DBS. Spillover is the intentional or unintentional overlapping of a satellite signal from one nation into the territory of another.

The technical issue of spillover also falls under the prior consent issue. As the satellites become more sophisticated it will be possible for the broadcaster to maintain a good deal of control over the direction of the signal. But, in certain areas of the world there may always be some inadvertent irradiation from the satellite. For those broadcasts not of a regional character, this may cause some international political friction.

47. 33 U.N. GAOR Committee on the Peaceful Uses of Outer Space (182d mtg.) at 43-44, U.N. Doc. A/AC. 105/PV.182 (1978).

48. 32 U.N. GAOR Committee on the Peaceful Uses of Outer Space (175th mtg.) at 42, U.N. Doc. A/AC.105/PV.175 (1977).

49. 31 U.N. GAOR Committee on the Peaceful Uses of Outer Space (160th mtg.) at 36, U.N. Doc. A/AC. 105/PV.160 (1976).

50. $1 d$.

51. 31 U.N. GAOR Committee on the Peaceful Uses of Outer Space (163d mtg.) at 27, U.N. Doc. A/AC.105/PV.163 (1976). 
The burden to control this problem will probably fall with the broadcasting rather than the receiving country.

If prior consent is accepted as a means to deal with spillover, it will probably come into effect in a limited number of situations. Exemptions will probably be provided in situations where the elimination of the spillover is technically impossible, as defined by the ITU Radio Regulations.... .

Consent would still be required where the spillover broadcast was aimed at a particular audience within the receiving state. Some provision promoting international consultations as a means to avoid dispute will probably . . receive support . . .52

Prior consent has an historical perspective in matters of spectrum control where nations have generally cooperated in assigning specific frequencies to particular activities such as broadcasting. Perhaps this perspective will permit more latitude in adopting measures to assure a receiving nation's initial participation in DBS program planning. The Fourth WGDBS Report included the following summary of prior consent issues:

Many delegations emphasized that no country should undertake satellite broadcasting to another country without the prior consent of the latter. Others expressed concern about the dangers inherent in, and potential abuses of, a broad principle of prior consent and underscored the importance of free speech and free flow of information. In this connexion, many delegations remarked that they did not see any contradiction between prior consent and free speech and free flow of information. ${ }^{53}$

\section{E. Noninterference}

The issue of noninterference also arose in the debate over the proper role of national sovereignty in DBS negotiations. A Polish COPUOS delegate noted: "Failure to secure prior consent would constitute a violation of the receiving State's sovereignty and, indeed, interference in its internal affairs." 54 As pointed out by the WGDBS, "The United Nations Charter, inter alia, specifies the sovereign equality of States . . . and the principle of noninterference in matters within domestic jurisdiction of any State." 55 The widely cited proposal presented to the WGDBS by Canada and Sweden in 1974 also links sovereignty, noninterference, and the free flow of information without necessarily making any element contingent upon the control of any other.

Direct television broadcasting by satellite shall be carried out in a manner compatible with the maintenance of international peace and security, the development of mutual understanding and the strengthening of friendly relations among all States and peoples. Such broadcasting shall also be conducted on the basis of respect for the principles of the sovereignty of States, non-intervention, and equality, and in the interest of promoting the free flow of communications . . . 56

52. Smith, Direct Broadeasting: Sixteen Years of Debale, 3 Satellite Com. 23 (1979).

53. 29 U.N. GAOR Committee on the Peaceful Uses of Outer Space at 13, U.N. Doc. A/AC.105/117 (1973).

54. 30 U.N. GAOR Committee on the Peaceful Uses of Outer Space (147th mtg.) at 32, U.N. Doc. A/AC.105/PV.147 (1975).

55. 24 U.N. GAOR Committee on the Peaceful Uses of Outer Space at 6-7, U.N. Doc. A/AC.105/66 (1969).

56. 29 U.N. GAOR Committee on the Peaceful Uses of Outer Space Annex III at 2, U.N. Doc. A/AC.105/127 (1974). 
A stricter interpretation of noninterference was presented by the German Democratic Republic:

The delegation of the German Democratic Republic proceeds on the assumption that the basis and criterion for legal norms for direct broadcast satellites are the basic principles of international law laid down in resolution 2916 (XXVII), namely respect for national sovereignty, the prohibition of interference in internal affairs of other States, the sovereign equality of States, and the principle of peaceful co-operation among States. This resolution was adopted by the General Assembly of the United Nations with 102 votes in favour, 1 vote against and 7 abstentions....

The incorporation of the concept of "free and unimpeded flow of information" in a future convention on direct broadcast satellites as proposed by some States, cannot, in our opinion, be supported by existing principles of international law. There is no legal norm in generally accepted international law which would permit this kind of flow of information. ${ }^{57}$

Bulgaria emphasized the absolute national right of any government to concern itself with all information, whatever the source.

$[O] n e$ must also take into account the fact that any State is competent to decide, in virtue of its sovereign right, all questions that pertain to the receiving of information through direct television broadcasting by satellite and that the control of foreign sources of information is a question that lies within the domestic jurisdiction of States. ${ }^{58}$

The Soviet Union linked individual rights with national sovereignty and the principle of noninterference, stressing that human rights cannot supersede international law since the freedom to pursue political and social development also means freedom from outside interference. The Soviet argument assumes that different rights cannot be separated out for individual scrutiny. The Soviet Union explained its position with reference to the freedoms identified in the Final Act of the 1975 Helsinki Agreement and the freedoms under discussion which could relate to satellite broadcasting. ${ }^{59}$ Romania interpreted the freedom of information principle to justify its opposition to any "regulations that may be contrary . . . to

57. 30 U.N. GAOR Committee on the Peaceful Uses of Outer Space (150th $\mathrm{mtg}$.) at 2, U.N. Doc. A/AC. 105/PV.150 (1975).

58. 35 U.N. GAOR Committee on the Peaceful Uses of Outer Space (212th mtg.) at 13-15, U.N. Doc. A/AC.105/PV.212 (1980).

59. 31 U.N. GAOR Committee on the Peaceful Uses of Outer Space (163d mtg.) at 52-57, U.N. Doc. A/AC.105/PV.163 (1976). The full text of this concept follows:

MR. KOLOSSOV (Union of Soviet Socialist Republics) (interpretation from Russian): At this late

hour our delegation decided to deal with only one item in our statement, that is, the item on the elaboration of principles governing the use by States of artificial earth satellites for direct television broadcasting.

Our delegation, which in its introductory statement assessed highly the positive results attained by the European Conference, notes with great gratification the fact that the principles adopted by this Conference are becoming increasingly recognized and that the Final Act concluded in Helsinki on 1 August 1975 has been referred to by an increasing number of delegations. We welcome this and in turn we should also like to draw attention to the significant importance of the document not only for the sake of the participating States but also for the sake of the entire world and all peoples, and we should like to draw the Committee's attention to some provisions of this document.

We note the fact that an attempt has been made to stress only one section of this document, which is a single unit. It is one package, and this is well known to the members of our Committee. It is not a matter of which Section of the Final Act should be discussed, but which principles governing international relations between States apply to our work. One of the delegations speaking today quoted the seventh principle of the Final Act, entitled "Respect for Human Rights and Fundamental Freedoms, Including the Freedom of Thought, Conscience, Religion or Belief." The Head of our State signed the Final Act, and obviously he also subscribed to this principle. But we should like to draw the Com- 


\section{the principles of sovereignty and the inadmissibility of interference in the internal}

mittee's attention to the fact that the following is stated in the preamble to this section containing the declaration of principles by which the participating States will be guided in their mutual relations:

"The participating States,

$\because$. . .

"Declare their determination to respect and put into practice, each of them in its relations with all other... States"-we stress: "with all other States'_.". . the following principles," - and very important words follow - "which are all of primary significance, guiding their mutual relations.".

Thus, in referring to this document, it becomes clearer to us that we should refer to all the other principles, to the aggregate total of the principles, and as Committee members will undoubtedly agree, a number of these principles are directly related to the problem of direct television broadcasting.

I shall not now read out all ten principles_representatives are quite familiar with this document-but we deem it necessary to read out a few words from Principle I, which is entitled "Sovereign Equality, Respect for the Rights Inherent in Sovereignty," which states as follows:

"The participating States will respect each other's sovereign equality and individuality as well as all the rights inherent in and encompassed by its sovereignty, including in particular the right of every State to juridical equality, to territorial integrity and to freedom and political independence. They will also respect each other's right freely to choose and develop its political, social, economic and cultural systems, as well as its right to determine its laws and regulations."

We could refer to Principle VI, "Non-intervention in Internal Affairs," and to Principle VIII, "Equal Rights and Self-Determination of Peoples." In the latter Principle it is specifically stated that:

". . . all peoples always have the right, in full freedom, to determine, when and as they wish, their internal and external political status, without external interference,"- - and, we stress again-"and to pursue as they wish their political economic, social and cultural development."

Do these principles apply to our work? The answer to this is given in a very important section of the Final Act devoted to cooperation in humanitarian and other fields, where there is a special section on information. In the preamble of that section it is stated clearly and directly that:

". . . this co-operation"-in the humanitarian field-_ "should take place in full respect

for the principles guiding relations among participating States as set forth in the relevant document"- that is, the principles heretofore mentioned.

Our State attached great significance to the human person, as mentioned at the recent Congress of our Party, as well as in our introductory statement. Everything that is done is done for man; we cannot imagine any field of law — be it diplomatic law, the law of the sea or outer space law - being formulated and set up for anything but man. Everything that is done is done for people-for all people, and for every man individually. But we can take any subject or object such as a house or a building, draw a dividing line through it and examine it at different levels. We can dissect the house horizontally, vertically or diagonally and each cross-section will be somewhat different, although we are studying the inside of the same house. Thus the question arises: How should we dissect this "house" in our Committee?

We believe that, in the light of the fact that everything is done for the sake of man, our Committee is concerned primarily with relations among States-I repeat: among States. That is, we are drafting the legal principles and norms of intergovernmental relations, and it is not by chance that the reports of our Committee are discussed in the First Committee of the General Assembly. This bears out my suggestion that we should dissect this "house" and look at its contents from the point of view of relations among States.

Our State, the Soviet Union, is a subscriber to the human rights covenants. We are gratified that these documents are quoted even by those delegations that have not ratified them, and we should like to stress once again that these covenants do not represent a unified code of criminal or civil law. They cannot replace the corresponding national codes; the codes of each State subscribing to the covenants remain in force. These covenants are not documents that give rights directly to man; no this is not what we are talking about here. We are talking about agreements among States to codify their national legislation or to adopt codes and legislation and rules which would be in keeping with the general norms and principles contained in these important documents. Not a single citizen of any country can say: "I do not recognize a national code; I am guided by the International Covenant on Civil and Political Rights." The covenant is not to be referred to by individuals, but, rather, as a document to be followed by those States that have ratified and signed it. 
and external affairs of States."60

A more conciliatory approach to the concerns of sovereignty and noninterference is reflected in a WGDBS report which acknowledges that satellite broadcasting, "if abused," could have "serious adverse effects," that such abuse could result in "recriminations," and that such broadcasting must, therefore, be in line with "international legal order" and based on "international cooperation."61 However, some WGDBS delegations did state specifically that regulation would be desirable to avoid "interference in the internal affairs of States, incitement to racial or religious intolerance, violation of fundamental human freedoms and possibly the use of subliminal techniques."62 Some also stressed the importance of prohibiting "war propaganda." 63 Worthy of note is the Canada/Sweden recommendation that, whatever international arrangements were to be made, they should certainly include "an element of mutual restraint."64

In the foregoing debate, noninterference, therefore, is perceived as recognition of the significance of national sovereignty and the importance of peaceful cooperation among states. Noninterference may also mean that human rights cannot supersede the state's right to develop socially and politically. Further, recognition ought to be given to the possibility that the deliberate abuse of satellite broadcasting could endanger international order, interfere substantially in internal affairs, incite intolerance, and otherwise encourage violations of human rights. The need for resolving these issues is seen by some as justification for mutual restraint.

\section{F. Avoidance of Conflict}

One pervasive concern underlying the issues of free flow and sovereignty is the possibility of international conflict created by propaganda broadcasts from space. The concern over conflict assumes that any protective reaction against unwanted broadcasts could profoundly disturb international relations.

It is obvious that a country might attempt to protect itself against unwanted or objectionable satellite transmissions, either by jamming the broadcasts, attempting to take over, or otherwise disturb, satellites belonging to other nations, by blocking needed international agreements on frequency allocations, etc., or by prohibiting within its territory the reception of satellite broadcasts, or the banning of the manufacture or importation of adequate receiving equipment. Such action could increase political tension on the international level. 65

A UN resolution entitled Preparation of an International Convention on Principles Governing by States of Artificial Earth Satellites for Direct Television

60. 30 U.N. GAOR Committee on the Peaceful Uses of Outer Space (15lst mtg.) at 26, U.N. Doc. A/AC.105/PV.151 (1975).

61. 24 U.N. GAOR Committee on the Peaceful Uses of Outer Space at 4-5, U.N. Doc. A/AC.105/66 (1969).

62. Id. at 10 .

63. Id.

64. 24 U.N. GAOR Committee on the Peaceful Uses of Outer Space at 8, U.N. Doc. A/AC.105/59 (1969).

65. 24 U.N. GAOR Committee on the Peaceful Uses of Outer Space at 70, U.N. Doc A/AC.105/49 (1969). 
Broadcasting, is "mindful of the need to prevent the conversion of direct television broadcasting into a source of international conflict and of aggravation of the relations among the States ...."66 The United Kingdom pointed out that "[d]ifferent political, social, cultural, [and] economic environments are likely to lead to disputes over the content of programme material which while acceptable in one country may be offensive in others," because "wide variations in culture and social customs may generate friction." 67

The avoidance of conflict in satellite broadcasting extends beyond the political, social, or economic realms of the industrialized nations, and poses a special challenge for developing nations which currently play limited roles in a highly technological world. Cultural and economic differences could be accentuated by DBS programming with detrimental results.

The Working Group recognizes that the use of direct broadcasts from satellites could considerably increase the knowledge of the peoples of all countries of current events in the world, and of each other's cultures, customs and beliefs and social interests. To this extent it could contribute significantly to improved international awareness, understanding and tolerance. If misused, however, this medium could disturb cultural, religious and social mores, particularly if programmes ridiculed the beliefs of others or contained items involving obscenity, violence or horror. Problems might also be caused by exposure to material emphasizing inequalities of standards of living. ${ }^{68}$

\section{G. Protection of Developing Nations}

Since such a wide discrepancy of communication development exists between the Third World and industrially advanced nations, special attention must be given to assuring participation by the developing nations. In the absence of such participation, free flow of information may have little meaning. One COPUOS delegate from Kenya has noted that while freedom of information may be a basic human right, it is the context of that freedom which grants it significance.

In our view the existence of choices does not in itself guarantee freedom. In the current flow of information in the world, for instance, we have little access to the sources or say in the shaping and dissemination of that information. We have no existence in the present-day information world. ${ }^{69}$

66. G.A. Res. 2916, 27 U.N. GAOR Supp. (No. 30) at 14, U.N. Doc A/8730 (1972). Similar early reminders are to be found in: G.A. Res. 110, U.N. Doc. A/519, at 14 (1947); G.A. Res. 381, 5 U.N. GAOR Supp. (No. 20) at 44, U.N. Doc. A/1775 (1950); G.A. Res. 424, 5 U.N. GAOR Supp. (No. 20) at 14, U.N. Doc. A/1775 (1950); G.A. Res. 634, 7 U.N. GAOR Supp. (No. 20) at 25, U.N. Doc. A/2361 (1952); G.A. Res. 841, 9 U.N. GAOR Supp. (No. 21) at 22-23, U.N. Doc. A/2890 (1954); G.A. Res. 1962, 18 U.N. GAOR Supp. (No. 15) at 15, U.N. Doc. A/5515 (1963); G.A. Res. 1963, 18 U.N. GAOR Supp. (No. 15) at 16-17, U.N. Doc. A/5515 (1963); G.A. Res. 2131, 20 U.N. GAOR Supp. (No. 14) at 11-12, U.N. Doc. A/6014 (1965); G.A. Res. 2222 Annex, 21 U.N. GAOR Supp. (No. 16) at 13-16, U.N. Doc. A/6316 (1966); G.A. Res. 2448, 23 U.N. GAOR Supp. (No. 18) at 52-53, U.N. Doc. A/7218 (1968); G.A. Res. 2915,27 U.N. GAOR Supp. (No. 30) at 12-14, U.N. Doc. A/8730 (1972).

67. 24 U.N. GAOR Committee on the Peaceful Uses of Outer Space at 13, U.N. Doc. A/AC.105.65 (1969). An "insider's" view by an observer from the Canadian Department of Communications, describing the stresses surrounding WARC 1979, can be found in: Segal, International Negotiations on Telecommunications, 8 INTER MEDIA 22 (1980).

68. 24 U.N. GAOR Committee on the Peaceful Uses of Outer Space at 10, U.N. Doc, A/AC.105/66 (1969).

69. 33 U.N. GAOR Committee on the Peaceful Uses of Outer Space (184th mtg.) at 73, U.N. Doc. A/AC.105/PV.184 (1978). The following offers unique insight into the potential effect of communications technology: 
Chile has linked freedom of information "with the inalienable right of peoples to defend their identity and their social and cultural heritage," 70 while Argentina has emphasized the gap between the developing and developed world by pointing out that ninety five percent of all research and development is carried out by nations having only thirty percent of the world's population, leaving only five percent of the world's capacity to seventy percent, and with "only the tiniest fraction of this small capacity" devoted to space activities. ${ }^{71}$ The overwhelming technolog. ical differences between the developing world and the industrialized nations, especially obvious in the exploitation of space, will continue to widen unless participatory roles are developed for Third World countries in DBS discussions.

Canada and Sweden warn "that direct broadcast satellites could become a virtual monopoly. . . used for political and commercial purposes to the exclusive advantage of those . . . able actively to participate in the launching and operation of space communication systems." 72 Though clearly committed to the free flow of information, the United Kingdom has also expressed reservations which suggest that developing nations should be given special consideration.

Widely different cultural and social climates and morals suggest that television broadcasts, whose content is viewed with equanimity in one State could prove abrasive in another. Programmes casting unfavourable light on different religious and social customs, e.g. concerning the role of women, might cause severe offense in some countries. What passes for obscenity or extreme violence in one society may frequently, because of a different cultural and sociological environment, be acceptable in others.

Less readily identifiable is the gradual change in political, social and cultural values which may be caused by continual exposure to material from abroad. While the free exchange of programmes may make a real contribution to mutual understanding, countries whose domestic television services are relatively under-developed and where foreign television broadcasts comprise the main source of information may be subject to cultural and political pressures of which they are scarcely aware. ${ }^{73}$

We shall lose perspective in interpreting the social implications of space science and technology if we fail to recognize that those developments form an important part of a wider set of diverging human functions. A characteristic property of such functions is best illustrated by understanding the meaning of a number expressed as a power, for instance, three raised to the power of eighteen, which is about 390 million. In dynamic terms it illustrates a very interesting feature of divergent functions. If a man were to spread a gossip to three other persons and each of these three would convey it to three others and so on, it would take just eighteen steps for all the people in a nation as large as India to know the spicy story. Note that if each step takes one hour, 90 per cent of the people get to learn the story only during the last two hours, the seventeenth and the eighteenth hours. Indeed during 80 per cent of the time, the process affects only 10 per cent of the population. All things which involve the human element, for example, population, knowledge and innovation, have this characteristic property. Like biological infection, which propagates almost unnoticed through many steps, but makes its onslaught felt all of a sudden, so too the social impact of innovative man has hit society like an avalanche. Scientific advances and technological innovations along with their social and political implications, have suddenly overtaken the pace of the human life cycle and produced a crisis of obsolescence.

23 U.N. GAOR Committee on the Peaceful Uses of Outer Space (Agenda Item 24) at 34-35, U.N. Doc. A/7285 [hereinafter cited as U.N. Doc. A/7285].

70. 35 U.N. GAOR Committee on the Peaceful Uses of Outer Space at 6, U.N. Doc. A/AC.105/PV.213 (1980).

71. 35 U.N. GAOR Committee on the Peaceful Uses of Outer Space (212th mtg.) at 11, U.N. Doc. A/AC.105/PV.212 (1980).

72. 24 U.N. GAOR Committee on the Peaceful Uses of Outer Space at 71, U.N. Doc. A/AC.105/49 (1969).

73. 24 U.N. GAOR Committee on the Peaceful Uses of Outer Space at 7, U.N. Doc. A/AC.105/65 (1969). 
The concern of developing nations for the potential mass effect of DBS appears to extend beyond the anticipated negative results of some cross-cultural conflicts, to stress the necessity for social or political integration. If DBS programming is to serve a constructive role in nation building, it must yield to some restrictions.

Indeed, as far as the developing countries are concerned, the free flow of information into the developing countries has proceeded to such an extent that I believe about 70 per cent of the television programmes in many of those countries come from Western countries. This, probably, is not the best form of free flow of information, but some aspects of this free flow of information are good, and speaking from personal experience within one country, I do not believe that I would want all the villages in India to get all their programmes from Delhi.

Indeed, as we go towards the operation of a direct broadcasting satellite in our country, we are forced to think of a system in which programmes are produced in hundreds of places, and we just use the high reach of the satellite, not to homogenize people but to integrate them. That is why we need agreements and consultations: so that this total programme of education and development is not tampered with, but so that the world does get integrated. We want to do it within our own country, and I believe it is necessary to do it throughout the world also. ${ }^{74}$

\section{H. Common Heritage}

A discussion of the issues which form the basis for developing a negotiable definition for propaganda in DBS agreements would not be complete without a brief reference to the "common heritage of mankind" principle of space activity. Any development of international regulations governing broadcasting from satellites "derive[s] from the concept of outer space as the common heritage of mankind," since "the indiscriminate use of outer space would constitute a flagrant violation of the clear legal obligations deriving from the international legal texts now in force." 75 Still as an ideal, this concept remains murky. Delbert D. Smith writes:

The "common heritage of mankind" seems to be intended as a legal concept since it governs, by definition, the disposition of property. What seems important is not the philological analysis of the words in the phrase, but the suggested general implications, and applications of the concept to various aspects of the international realm. At present the phrase "common heritage of all mankind" has been given no clear definition. Nor is it clear whether the international community desires a single, universal definition of common heritage to apply in all the spheres where it can be utilized. ${ }^{76}$

The common heritage principle does not really contemplate that all nations will have equal access to outer space. The UN resolution entitled International Co-operation in the Peaceful Uses of Outer Space states that the "use of outer space should be only for the betterment of mankind and to the benefit of States irrespective of the stage of their economic or scientific development."77 However, "access" is the result of successful development of hardware, programming, and economically favorable circumstances. While space may be the world's common

74. 34 U.N. GAOR Committee on the Peaceful Uses of Outer Space (192d mtg.) at 11, U.N. Doc. A/AC.105/PV.192 (1979).

75. 35 U.N. GAOR Committee on the Peaceful Uses of Outer Space (213th mtg.) at 6, U.N. Doc. A/AC.105/PV.213 (1980).

76. D. Smith, Space Stations: International Law and Policy 162 (1979).

77. G.A Res. 1721, 16 U.N. GAOR Supp. (No. 17) at 6-7, U.N. Doc. A/5026 (1961). 
heritage in theory, actual access is available mainly to the industrialized nations, and remains a dream for the rest.

This section, in attempting to provide a perspective on the challenges to developing a proposal for a negotiable definition of propaganda, has come full circle. The DBS debate, now approaching the end of a second decade, underscores the significance of individual rights on a global scale and struggles for recognition of those rights as they are expressed in the principle of the free flow of information. Yet the debate is challenged by concerns for national sovereignty, prior consent, noninterference in internal affairs, avoidance of international conflict, and the special needs of developing nations. These are the issues which affect the development of a negotiable definition of propaganda.

\title{
IV
}

\section{TOWARds a Negotiable Definition}

\begin{abstract}
We must recognize that despite our earlier hopes broadcasting has not turned out to be the means of international understanding that we once imagined it might be. On the contrary (and speaking particularly of television), broadcasting today seems to have turned inwards and become the instrument of increased nationalism. Our screens do not reflect the pulse of world events, but rather the feebler beats of life at home, and when we get the occasional glimpse of larger issues, they tend to be seen from a selfish, national viewpoint. ${ }^{78}$
\end{abstract}

Whatever objectives are involved in the effort to control DBS programming, one must remember that broadcasting is universally viewed as a national service. "Historically, both telecommunications and mass media have developed according to the concept of a national prerogative . . . based on national structures that have served as a point of departure for . . . international cooperation." 79 Such a perspective tends to make international negotiations all the more sensitive.

The international nature of the DBS, as described earlier, has spurred much debate, generally about broad principles of worldwide concern. Out of these discussions, prior consent emerges as a key concept reflecting global concern for the preservation of national sovereignty while confronting the advocates of the free flow of information. Any negotiations to develop mutual agreement on acceptable DBS programming must take into account differing national and regional social needs, cross-cultural problems, differing stages of national media development, differing media policies, differing languages and time zones, social acceptability of programming, ${ }^{80}$ and the conflict between the principles of prior consent and free flow of information. The next two sections will attempt to suggest the guidelines for negotiating a definition of propaganda which takes into account the issues raised by DBS. This section will first examine briefly the heritage of international propaganda, and then analyze those elements essential to a definition. Finally, an approach to encourage negotiation will be suggested.

78. D'Arcy, supra note 17, at 1-2.

79. 24 U.N. GAOR Committee on the Peaceful Uses of Outer Space at 5, U.N. Doc. A/AC.105/49 (1969).

80. 24 U.N. GAOR Committee on the Peaceful Uses of Outer Space at 77-78, U.N. Doc. A/AC.105/ 49 (1969) 


\section{A. Heritage of International Propaganda}

While the history of international propaganda is far too extensive and complex for adequate description in this short space, some observations can be made. First, and most obvious, propaganda is used as a negative term. Leonard Doob wrote, "An effective way in Anglo-Saxon society to insult, belittle, or expose a man is to call him a propagandist."81 The vivid heritage of propaganda, highlighted during the Nazi era of World War II, has come to be characterized by devious acts performed by men who used radio and other media for evil ends. While the Nazis were rising to power, the League of Nations sponsored the 1936 International Convention Concerning the Use of Broadcasting in the Cause of Peace, the first three articles of which specifically identify harmful broadcasting as interference with the internal affairs of another nation, inciting aggression, and harming international relations. ${ }^{82}$

Between the drafting of this document and the concepts of shared information embodied in the Conference on Security and Cooperation in Europe: Final Act, ${ }^{83}$ signed at ${ }^{\circ}$ Helsinki, August 1, 1975, the fields of electronic communications, space technology, and information policy have been brought together, at times under circumstances of confrontation over programming control. Since any information is apt to be labelled as propaganda when its contents are identified as belligerent

81. L. DoOb, Public Opinion and Propaganda 231 (2d ed. 1966). Among the many texts dealing specifically with propaganda, its history, techniques and social roles, are three recent works: M. BALFOUR, Propacanda in War 1939-1945: Organizations, Policies and Publics in Britain and Germany (1979); J. Hale, Radio Power: Propaganda and InTErnational Broadcasting (1975) (extensive bibliography); H. Lasswell, D. Lerner \& H. Speier, Propaganda and Communication (1979-80) (3 vols.).

82.

Article 1

The High Contracting Parties mutually undertake to prohibit and, if occasion arises, to stop without delay the broadcasting within their respective territories of any transmission which to the detriment of good international understanding is of such character as to incite the population of any territory to acts incompatible with the internal order or the security of a territory of a High Contracting Party.

Article 2

The High Contracting Parties mutually undertake to ensure that transmissions from stations within their respective territories shall not constitute an incitement either to war against another High Contracting Party or to acts likely to lead thereto.

\section{Article 3}

The High Contracting Parties mutually undertake to prohibit and, if occasion arises, to stop without delay within their respective territories any transmission likely to harm good international understanding by statements the incorrectness of which is or ought to be known to the persons responsible for the broadcast.

They further mutually undertake to ensure that any transmission likely to harm good international understanding by incorrect statements shall be rectified at the earliest possible moment by the most effective means, even if the incorrectness has become apparent only after the broadcast has taken place.

International Convention Concerning the Use of Broadcasting in the Cause of Peace, Sept. 23, 1926,186 L.N.T.S. 309, Nos. $4301-4327$ (1938).

83. Conference on Security and Cooperation in Europe: Final Act, Aug. 1975, reprinted in 73 DEP'T STATE Bull. 323 (1975), in 14 INT'L L. Materials 1292 (1975), and in 13 VAND. J. Transnat'L L. 575 (1980).

President Ford stated: "I would emphasize that the document I will sign is neither a treaty nor is it legally binding on any participating state. The Helsinki documents involve political and moral commitments aimed at lessening tensions and opening further the lines of communication betweeen the peoples of East and West." E. MCDOWell, Digest of United States Practice in International LaW 325 (1975). 
or destructive, a negotiable definition would be difficult to achieve, even under the best circumstances.

However, every government has a vested interest in favorable relationships. As Harold Laswell wrote about the international scene that existed before radio, television and satellites:

The truth is that all governments are engaged to some extent in propaganda as part of their ordinary peace-time functions. They make propaganda on behalf of diplomatic friends or against diplomatic antagonists, and this is unavoidable. While, therefore, the presumption exists against propaganda work by a democratic government this statement should not be taken too literally. ${ }^{84}$

During recent congressional hearings on appropriations for Radio Free Europe and Radio Liberation, the belligerence of international radio broadcasting was lauded by Representative Edward J. Derwinski:

I endorse the action of the Subcommittee on International Operations and the Committee on Foreign Affairs in strengthening our commitment to Radio Free Europe and Radio Liberty. Most of my colleagues on the subcommittee and the full committee support, as I do, these radios in the effort to take the truth to the Communist world. I believe that we are involved in nothing less than a "radio war" with the Soviet Union . . . .

I also wish to reemphasize the importance of our broadcasts in Russian and Ukrainian. The massive Soviet jamming effort directed against broadcasts in these priority languages must be overcome.

I would have preferred more money for the conduct of the radio war despite the budget constraints under which we are operating. The Congress, the administration, and the American people must be educated to think of the radios as weapons-albeit nonlethalkey elements in our national security. ${ }^{85}$

This description of a "radio war" apparently reflects the tacit assumption that "it is unlikely that . . . any vast changes in accepted orders in history" are "not accompanied by some kind of psychological warfare." 86 It seems inevitable that in these days of international tension, most mass transmission of information by governments becomes mass persuasion. This account by a former U.S. Information Officer describes such a tendency from a personal perspective:

If we are to have the kind of world we want, we must go beyond traditional diplomacy to influence the opinions and attitudes of these men and women.

This means engaging in propaganda, a label most people might apply to the utterances of their opponents but never to their own. When I joined the U.S. Government's foreign information program in 1951, I had the typical liberal's suspicion of the word. I did not consider my colleagues and my self to be "propagandists." We were disseminating only "information" designed to "tell America's story to the world," and our hope was that if others could come to know us better they would learn to appreciate, respect, and sometimes even love us.

I was wrong; it is not that simple. I spent most of the 1950 s as a government Information Officer abroad, and I found that merely "informing" people was not enough. We had to make a case for our views, as others were doing for theirs. We had to be advocates, persuaders-propagandists. We did not lie, or distort the news, or subvert the media, but neither were we disinterested. We accomplished no miracles, but had we not been propagandists we would have accomplished nothing. ${ }^{87}$

84. H.D. Lasswell, Propaganda Technique in World War I 14 (1971).

85. H.R. ReP. No. 971, 96th Cong., 2d Sess. 22, 23 (1980).

86. G. GORDON, I. FALK \& W. HOdAPP, THE IdEAS INVADERS 18-19 (1963).

87. T. SOrenson, The Word War: The Story of American Propaganda x (1968). 
Among numerous UN references to the threat of uncontrolled propaganda is a 1947 resolution entitled Measures to be Taken Against Propaganda and the Inciters of a New War, which specifically "Condemns all forms of propaganda, in whatsoever country conducted, which is either designed or likely to provoke or encourage any threat to the peace, breach of peace, or act of aggression." 88 These same words appear nineteen years later in the preamble of the 1966 Treaty on Principles Governing the Activities of States in the Exploration and Use of Space, Including the Moon and Other Celestial Bodies, ${ }^{89}$ and also in the UN Resolution 1962 (XVIII) entitled Declaration of Legal Principles Governing the Activities of States in the Exploration and Use of Outer Space, adopted unanimously December 13, 1963. ${ }^{90}$ At this point, it is appropriate to note article I, chapter I, of the United Nations Charter, which states the purpose of the UN:

To maintain international peace and security, and to that end: to take effective collective measures for the prevention and removal of threats to the peace, and for the suppression of acts of aggression or other breaches of the peace, and to bring about by peaceful means, and in conformity with the principle of justice and international law, adjustment or settlement of international disputes or situations which might lead to a breach of the peace. $^{91}$

\section{B. Definitions of Propaganda}

Propaganda has been defined as "the activity, or the art, of inducing others to behave in a way in which they would not behave in its absence." 92 In a broader sense, propaganda can be described as "a systematic attempt through mass communications to influence . . thinking and . . . behavior."93 A slightly more critical description holds that "[p]ropaganda is the preconceived, systematic and centrally coordinated process of manipulating symbols, aimed at promoting uniform behavior of large social groups, a behavior congruent with the specific interests and ends of the propagandist."94 Propaganda has also been described within COPUOS as a hostile act, whose characteristics include the following:

(1) Broadcasts making war propaganda which provoke the mentality of the people of receiver countries towards the initiation of war.

(2) Broadcasts which incite subversive activities against the political institutions of receiver countries.

(3) Broadcasts which slander receiver countries or their representative organs and injure the dignity and honour of receiver countries.

(4) Broadcasts which interfere in the internal affairs of receiver countries by criticizing their policies and incite the people not to follow their policies.

(5) Broadcasts which violate basic human rights are offensive to the race, belief, religion, etc., of the receiver countries' people. ${ }^{95}$

Finally, one UN resolution, entitled Condemnation of Propaganda Against

88. G.A. Res. 110, U.N. Doc. A/519, at 14 (1947).

89. Basic Documents in InTERnational LaW, supra note 29, at 105.

90. 18 U.N. GAOR (1280th plen. mtg.) (Agenda Item 28) at 1, U.N. Doc. A/RES/1962 (1965)

91. BASIC DOCUMENTS IN INTERnATIONAL. LAW, supra note 29, at 3.

92. L. Fraser, Propaganda 1 (1962).

93. L. Martin, International Propaganda: Its Legal and Diplomatic Control 12 (1958)

94. B. Hazan, Soviet Propaganda: A Case Study of the Middle East Conflict 12 (1976).

95. 25 U.N. GAOR Committee on the Peaceful Uses of Outer Space at 7, U.N. Doc. A/AC.105/79 (1970). 
Peace, links aggression with censorship when defining propaganda and recommends the free exchange of communication as a foundation of peace.

The General Assembly

1. Reaffirms its resolutions 110 (II) and 290 (IV), paragraph 8, which condemn all propaganda against peace and recommend the free exchange of information and ideas as one of the foundations of good neighbourly relations between the peoples;

2. Declares that such propaganda includes:

(1) Incitement to conflicts or acts of aggression;

(2) Measures tending to isolate the peoples from any contact with the outside world, by preventing the Press, radio and other media of communication from reporting international events, and thus hindering mutual comprehension and understanding between peoples;

(3) Measures tending to silence or distort the activities of the United Nations in favour of peace or to prevent their peoples from knowing the views of other States Members. ${ }^{96}$

Indeed, numerous statements, resolutions, and proposals identify the anticipated threat of international propaganda. To make matters worse, the issues of individual rights, national sovereignty, prior consent, and noninterference combine in a web of competing ideologies against the background of historical misuse of information. The heritage of propaganda, and the continuing debate over how to regulate DBS programming, make the goal of developing any negotiable definition almost impossible. Despite this negative picture, it is possible to extract certain elements conducive to negotiation.

\section{An Approach to Negotiation}

Many feel that national sovereignty and the free flow of information are not irreconcilable, provided that prior consent is not perceived as a pure act of censorship but as an exercise of sovereign rights within the context of international cooperation.

[T] he concepts of freedom of information and national sovereignty need not necessarily be mutually exclusive. If freedom of information could be within the framework of international co-operation and understanding, and consent could be construed in terms of the exercise of sovereign rights to be protected against possible dissemination of information that might undermine a country's cultural and traditional values, then it is possible to find some acceptable formulations to reflect these concerns. ${ }^{97}$

However, any proposal regarding rights or sovereignty must be more flexible than that recommended by the United States.

[I] want to reaffirm our position that direct broadcast principles must not infringe upon the internationally recognized right to seek, receive and impart information and ideas through any media and regardless of frontiers. In saying that, at the same time, we recognize that States have interests, concerns and sensitivities related to direct broadcasting by satellite. These are alleviated by the fact that such broadcasts would have to be conducted in accordance with the International Telecommunication Union technical regulations. We believe that a solution to any remaining problems can be found by means of a principle calling for consultations before the commencement of a direct broadcasting service by satellite, if the intended receiving State so requests. These consultations will enable a State to present its

96. U.N. Res. 381, 5 U.N. GAOR Supp. (No. 20) at 14, U.N. Doc. A/1775 (1950).

97. 31 U.N. GAOR Committee on the Peaceful Uses of Outer Space (160th mtg.) at 42, U.N. Doc. A/AC.105/PV.160 (1976). 
views and interests to the State which proposes to establish or authorize such a service in order that they may be taken into account and be given due regard. ${ }^{98}$

While DBS coverage could be controlled by directional antennas, only three satellites are required theoretically to reach almost all the earth's population. This prospect of world wide coverage appears to be the basic reason for the current statements in negotiations which have as their goal universal acceptance. To be negotiable, therefore, any definition of propaganda involving the DBS must have a regional context. Only regional effects can avoid the current confrontation of diametrically opposed principles.

In a regional context, the conflicts of human rights versus states' rights, national sovereignty and political ideology, and the differences between the industrialized and developing Third World have a greater opportunity to be resolved when fewer nations having similar ideologies and goals are able to work together. Instead of continuing to attempt to reach the apparently impossible goal of universal commitment to the unrestricted flow of information, groups of nations with regional and aspirational similarities could develop mutually acceptable DBS arrangements. The "negotiable" approach to propaganda could include two phases: first, reaching agreement on what constitutes acceptable and unacceptable DBS programming; and, second, developing mechanisms to encourage and implement regional agreement.

At the very least, the UN General Assembly, the Committee on the Peaceful Uses of Outer Space, or UNESCO, could take steps to identify specific DBS programming that would not be labelled as propaganda. Such action, through general debate, might engender a negotiable definition of propaganda by determining program content that is not propagandistic. While the choice of programming may be severely limited, some constructive compromise might be achieved. For example, UNESCO or COPUOS may reach an agreement that the Olympics, World Cup Finals, weather forecasts, and natural disaster reports are not propagandistic. With such specificity, DBS discussions may be able to achieve negotiated resolutions. In the event that the General Assembly or COPUOS cannot reach any agreement, the debate might still serve to clarify the issues and identify possible regional approaches to acceptable programming - the second step in this proposal.

Having debated specific DBS programming in a global context, the UN could then more effectively carry out the mandate of the 1972 UNESCO Declaration of Guiding Principles on the Use of Satellite Broadcasting for the Free Flow of Information, the Spread of Education and Greater Cultural Exchange, that "Broadcasters and their national, regional and international associations should be encouraged to co-operate in the production and exchange of programmes and in all other aspects of satellite broadcasting . . . ."99 Discussion could be held on a regional basis.

98. 34 U.N. GAOR Committee on the Peaceful Uses of Outer Space (193d mtg.) at 46, U.N. Doc. A/AC. 105/PV.193 (1979).

99. Declaration of Guiding Principles, supra note 32, art. VIII. The recommendation for regional agreements arose frequently in COPUOS discussions as well as in formal proposals such as those submitted by Canada and Sweden, supra note 4. 
To say that propaganda must concern itself with controversial topics would be tautological. Controversy can exist only when there are two sides to a question. If the interests of an ingroup are promoted, then obviously there must be two sides to the question; otherwise the interests of the in-group would be similar to those of the out-group, that is, universal, and there would be no propaganda. ${ }^{100}$

It has been proposed that negotiations, concerned with taking issues of propaganda out of specific programming, be conducted first on a global then a regional level. This two-tiered approach, first allowing for debate through the UN General Assembly, UNESCO, or COPUOS, then on a regional basis, refines the present generalized exchange of views. The next section suggests some means for organizing regional discussions and implementing any agreements reached.

\section{$\mathrm{V}$ \\ IMPLEMENTATION}

Several organizations have discussed the DBS and related issues-COPUOS, which has been limited to a somewhat repetitious exchange of ideas and philosophies, UNESCO, and the ITU. The ITU is a specialized agency of the UN responsible for telecommunications and is the oldest of all international organizations, dating back to the International Telegraph Union founded in 1865. Its UN relationship began at the 1947 Atlantic City Conference. Headquartered in Geneva, Switzerland, the ITU "strives to improve the effectiveness of the international network, to ensure that each nation's network works harmoniously and compatibly with others, and in pursuit of that goal promotes the broadest application of modern technology."101

Although there are some questions as to its adaptability to the current state of communications technology, the ITU remains for many, "the best managed and cost-effective of all [international organizations], serving as the foundation for a rational telecommunications world and encouraging order, common purpose, and dedicated international cooperation." 102

The UN context for discussions is very different from the ITU context. In the UN, space matters were first taken up in connection with issues of disarmament and the first concern was to prevent an extension of the Cold War into outer space. A Committee on the Peaceful Uses of Outer Space was established, known as COPUOS or, more usually, as the Outer Space Committee. Soon, the UN involvement expanded to encompass the elaboration of a totally new branch of international law: space law. Its major achievement in this area was to establish the basis of the Outer Space Treaty of 1967, which "internationalizes" outer space, and has since been followed by specific agreements on various aspects of outer space activities such as the rescue of astronauts and the liability for damages caused by space activities.

The treaty was the background for the work on legal principles for satellite broadcasting which started in 1969. From 1969 to 1974 the Outer Space Committee had a special Working Group on Direct Broadcast Satellites. After 1974, space matters were dealt with

100. L. MARTIN, supta note 93, at 12.

101. O'Neill, The Intemational Telecommunication Union, TELECOMMUNICATIONS, Feb. 1981 at 25.

102. Id. For a detailed analysis of the ITU see D. LEIVE, INTERnAtional Telecommunications and INTER National LaW: The Regulation OF THE Radio Spectrum (1970) and D. SMTTH, INTERNational Telecommunication Control: InTERnational LaW and the Ordering of Satellite and OTHER FORMS OF INTERNATIONAL BROADCASTING (1969). 
by its legal Sub-Committee. It has been hard and long work. Agreement in principle has been reached on all major provisions except on the key issue of "prior agreement." 103

The issues revolving around the division of the radio spectrum, the allocation of parking orbits for satellites, and the standardization of electronic equipment, are for the most part susceptible to resolution by mutual agreement on a regional and/or global basis. The success of the ITU in achieving general international agreement on many of these specific matters lends hope for resolving the problems of acceptable DBS programming. In ITU activities, there is the recognition that national interests must continue to play a part in a "communications system that is by definition of a supranational nature."104

Each of these organizations has examined DBS issues in a global context but they have not come to any agreements on DBS programming. A mechanism is needed to encourage such specific agreements. To develop such a mechanism, regional organizations designed specifically to formulate programming agreements should be established. These regional organizations, although organized by the UN, would serve a regional constituency concerned with local matters of particular interest to the participants, while maintaining UN goals of international cooperation.

An example of achieving international cooperation in television programming (whether internationally broadcasted or exchanged) as a result of formal regional organizations is the European Broadcasting Union (EBU).

The active membership of EBU, created in 1950 to succeed the International Broadcasting Union founded in 1925, consists of one or more broadcasting organizations in thirty countries within the European Broadcasting Area as defined by the ITU which includes the eastern Mediterranean and north Africa. There are also associate (nonvoting) members in thirty-four countries outside the area; they have the same basic rights as active members except the right to vote. The Union is nongovernmental, nonpolitical and noncommercial. It exists to promote the study of common problems and the exchange of information, to assist the development of broadcasting and to facilitate multilateral and bilateral exchanges and coproductions of radio and television programmes. By means of microwave links and cables, it maintains a permanent rented network of sound, vision, and control circuits. The network can be linked, via earth stations, with satellites. ${ }^{105}$

Major DBS issues, debated as they are in a universal forum with little hope of solution, may be more manageable on a regional basis. As Delbert D. Smith noted regarding the EBU, "Regional organizations may prove to be the key to eventual international cooperation on a permanent basis." 106

The ITU has also worked reasonably well because it has used this approach in dealing with a physical phenomenon, the radio spectrum. Two ITU organs, the International Radio Consultative Committee (CCIR) and the International Telegraph and Telephone Consultative Committee (CCITT), and their study groups, operate on this specialized level. ${ }^{107}$ All members of the ITU and some private com-

103. Broadcasting: The Law is Confused, 8 INTER MEDIA 11 (1980) (emphasis added).

104. 23 U.N. GAOR (1583d mtg.) (Agenda Item 26) at 14, U.N. Doc. A/C.1/PV. 1583-1649 (1968) A short summary of ITU structure and functions can be found in O'Neill, supra note 101, at 25-26. 97.

105. UNESCO, WORld COMmUnications: 200 COUNTRy Survey OF Press, Radio. Television AND FILM 22-23 (1975).

106. D. SMITH, supra note 102 , at 114 .

107. Kirby, Getting the Message Across: the Role of the International Consultative Commiltees in Global Communications, TELECOMMUNICATIONS 27-30 (1981). 
panies, as well as scientific and industrial organizations, can participate in both committees. International agreement assigns to the CCIR the study of those technical and operational questions related to radio communications along with the issuance of recommendations. The CCITT has a similar mission regarding technical, operational, and tariff issues concerning telegraphing and telephoning. A number of study groups, whose membership includes widely-known experts, conduct much of the work of these two committees. "The high quality product of these study groups is the basis for standards and specifications that are accepted by all administrations and users." 108

This author proposes that regional administrations be set up, under the auspices of the ITU (or some other UN body) to include those nations which share common boundaries and interests in DBS, solely for the purpose of developing broadcast services and negotiating acceptable programming within their own region for their particular interests. Regional administrations could be set up, perhaps, for example, in such areas as the South Pacific and different geographic regions in Africa, Europe, or South America, where there exist similar economic problems, aspirations, national goals, political interests, and social concerns. Admittedly, problems may arise from spillover issues affecting nonmembers who have contiguous boundaries, but at least the forum of discussion would be local and therefore likely to encourage local solutions. Some spillover problems may be alleviated by directional antennas aboard the DBS to confine the broadcast area.

Not all regions, however defined, will be able to establish such administrations, but the fact that one area cannot solve its problem should not preclude another from succeeding. Moreover, the successful experiences of one area may serve to assist others. If regional organizations such as the EBU can operate successfully, there is reason to believe that UN regional administrations for DBS program development can succeed. Programming content, presently labelled propaganda when universally applied, may become negotiable on a regional basis.

In summary, it is proposed that discussions of specific DBS programming take place first in the UN to discover whether any subject matter can be considered nonpropagandistic, and later at the regional level. Implemented through regional administrations, such discussions would encourage cooperation where there is mutuality of interest, while avoiding the historical problems raised by promulgating national philosophy as universal principle.

\section{VI \\ CONCLusion}

A UN delegate once observed that regulating activities in outer space was "disarmament in advance." 109 Unfortunately, the history of international DBS negotiations appears to confirm that observation. While the DBS has always had the potential for enlightenment, it has also been a potentially effective weapon of

108. O'Neill, supra note 101 , at 97.

109. 21 U.N. GAOR Committee on the Peaceful Uses of Outer Space (142d mtg.) at 432, U.N. Doc. A/C. 1/SR/492 (1966). 
propaganda. These conflicting concerns, so far unresolved, confirm the statement that "if there is one field of activity in which scientific discovery and technical progress have significant social effects likely to involve new institutional adjustments, it is undoubtedly the field of mass communication media."110 Although Canada, Australia, the Soviet Union, India, the United States, France, Germany, Japan, and some Arab countries, ${ }^{11}$ have developed, or are in the process of developing, national services, much remains to be done before an international service can be established.

To become negotiable in this age of the DBS, the definition of propaganda must be resolved on a regional basis. Since "globally accepted rules and international agreements do not exist at present,"112 and because the "diversity of cultures" makes agreement extremely difficult if the negotiating principles are to be based on "respect for national cultures and State sovereignty,"113 the regional approach appears to be the only solution.

The Canada/Sweden DBS proposal typifies the suggestions which, so far, have stressed "bilateral and international co-operation" and "improved co-ordination." 114 The fifth session of the WGDBS concluded, "International co-operation is a touchstone for the development and use of direct television broadcasting by satellite," and recognized the role of regional organizations in achieving this goal. ${ }^{115}$ This theme, reiterated for more than a decade, was enunciated clearly in a 1970 WGDBS report.

The Working Group therefore foresaw the establishment and operation of regional satellite broadcast systems and programme planning and production for such system on the basis of regional co-operation. In fact, regional arrangements could be based on the principle that the countries receiving the signal transmitted by a satellite would participate in the planning and preparation of programmes, or else in the management and operation of a regionally based system. While it was envisaged that co-operative arrangements for programme planning and production would be primarily among broadcasters and broadcasting associations, it would be a matter for Governments to decide the basis on which their countries would participate in direct broadcasting activities, taking into account the international obligations of States. ${ }^{116}$

110. F. Terrou, The Need for International Agreements, Communication in the SPACE AGE 169 (1968).

111. Satellite Chart, supra note 1 , at 24.

112. 24 U.N. GAOR Committee on the Peaceful Uses of Outer Space at 9, U.N. Doc. A/AC.105/66 (1969).

113. Id.

114. 24 U.N. GAOR Committee on the Peaceful Uses of Outer Space at 25, U.N. Doc. A/AC.105/59 (1969).

115. 29 U.N. GAOR Committee on the Peaceful Uses of Outer Space at 11-12, U.N. Doc. A/AC.105/ 127 (1974).

116. 25 U.N. GAOR Committee on the Peaceful Uses of Outer Space at 8, U.N. Doc. A/AC.105/83 (1970). This report also stated the following:

The Working Group agreed that present experience and practices of the regional broadcasting unions would be significant for future broadcasting from satellites. While recognizing the different structures and roles of broadcasting in different countries, the Working Group noted that the existing regional co-operation between broadcasters with regard to procedures concerning programme content in regional or international television transmissions, might serve as a basis for arrangements concerning broadcasting from satellites. The reason for the success of these regional undertakings could be found in the recognition of common programme interests and requirements and in the underlying principle of voluntary agreements concerning programme content based on co-operation and participation in programme formulation and on non-interference in the programming policies of the individual member-organizations. 
This study has formalized such general proposals for cooperation by suggesting that under the auspices of the UN, regional administrations be set up to address matters of acceptable DBS programming and to encourage negotiations among nations sharing common geographical areas. The premise underlying this proposal is found in a statement made by a COPUOS delegate from India, who declared, "In fact, we need an international framework in order to make international television possible - and not the other way around."117 The purpose of regional administrations, therefore, would be to provide a structure within which negotiations over acceptable DBS programming can best take place.

The other half of this proposal recommends that specific programs or services be discussed at the global (UN, COPUOS, or UNESCO) level, as well as through regional administrations. It is hoped that this would foster some general international agreement on acceptable DBS programming, as well as stimulate the process of negotiation on a more local level. The free flow of information might be a trickle at first, but the principle would have its best opportunity for global acceptance if first granted some regional acceptance. "And of course, a country cannot simply extend its domestic policies into the international arena, since it must also consider, and to a certain extent accommodate, the interests of other nations."'118 There is hope for compromise.

United States information policies in the international arena will inevitably reflect the assumptions of United States domestic information policies. Since no two nations have precisely the same domestic information policy assumptions, however, accommodations occasionally will have to be made between differing, and sometimes competing, international information policies. . . The international arena is not unique in that balances and tradeoffs are continually required in domestic information policy as well. There are no absolutes, but rather only other competing interests, exceptions, and mitigating circumstances-all leading to compromise and, ideally, consensus. Moreover, the balances to be achieved are not static, because the environment is not static. An ever-changing technological environment lends a dynamic element to this issue which only serves to ensure that whatever agreements and accords are reached must be flexible and amenable to change. ${ }^{19}$

France has stated that "there can be freedom of dissemination of information .. . provided that abuses are not protected together with the right, because that would devalue freedom while trying to protect it." 120 This freedom should be founded upon a disciplined approach, "with a view to protecting the freedom of all," 121 and based "upon consultations and freely negotiated agreements." 122 If the definition of propaganda is to be negotiable, a new approach is needed, because "obsolescence of thinking and patterns of behaviour in international affairs pose today a most serious threat to our survival."'23

If the evolution of communications technology has any significance in the

117. 34 U.N. GAOR Committee on Peaceful Uses of Outer Space (192d mtg.) at 12, U.N. Doc. A/AC.105/PV. 192 (1979).

118. A. Bushkin \& J. YUROW, supra note 28, at 2.

119. Id. at 5 .

120. 32 U.N. GAOR Committee on the Peaceful Uses of Outer Space (173d mtg.) at 13-15, U.N. Doc. A/AC.105/PV. 173 (1977).

121. Id.

122. Id.

123. U.N. Doc. A/7285, supra note 69 , at 16. 
international arena, it is to reaffirm the interdependence of nations. The lessons of global communications, like those of international economics, illustrate in unmistakable terms that all nations must learn to adapt in order to survive. Although broadcasting from space can offer the possibility of global community, the DBS so far has been perceived mainly as a technical circumstance encouraging crossnational confrontation of ideologies and cultures. This situation will be resolved only when nations are willing to practice the art of accommodation with skill and grace. 


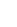

